$\mathrm{A} \int_{\text {ars }} \mathrm{H}$

Received : 21.06.2016

Revised : 14.11 .2016

Accepted : 24.11.2016
Members of the Research Forum

Associated Authors:

${ }^{1}$ Department of Horticulture, C.C.S.

University, MEERUT (U.P.) INDIA

${ }^{2}$ Department of Horticulture, C.C.R. (P.G.) College, MUZAFFARNAGAR (U.P.) INDIA
Author for correspondence : J.P.SINGH

Department of Horticulture, Gochar Mahavidhyalaya, Rampur

Maniharan, SAHARANPUR (U.P.) INDIA
THEASIAN JOURNALOF HORTICULTURE

Volume 11 | Issue 2 | December, 2016 | 382-386 Visit us -www.researchjournal.co.in

\title{
Effect of $\mathrm{GA}_{3}$ and Azotobacter on growth and flowering in African marigold (Tagetes erecta L.) cv. PUSANARANGI GAINDA
}

\section{NARESH KUMAR ${ }^{1}$, JITENDRA KUMAR ${ }^{1}$, J.P. SINGH, HIMANSHU KAUSHIK $^{1}$ AND R.K. SINGH ${ }^{2}$}

ABSTRACT : The field experiment was conducted at Horticulture Research Farm of Choudhary Charan Singh University campus, Meerut U.P. during 2011-12. The nine treatments $\mathrm{A}_{1}$ (Azotobacter by root treatment $0.20 \mathrm{~g} / 15$ plants), $\mathrm{A}_{2}$ (Azotobacter by soil treatment $0.40 \mathrm{~g} / \mathrm{plot}$ ), $\mathrm{G}_{1}$ (Gibberellic acid $100 \mathrm{ppm}$ spray at $\left.30 \mathrm{DAT}\right), \mathrm{G}_{2}$ (Gibberellic acid $150 \mathrm{ppm}$ spray at $\left.30 \mathrm{DAT}\right)$, $\mathrm{A}_{1} \mathrm{G}_{1}$ (Azotobacter by root treatment $0.20 \mathrm{~g} / 15$ plants and gibberellic acid 100 ppm spray at 30 DAT), $\mathrm{A}_{1} \mathrm{G}_{2}$ (Azotobacter by root treatment $0.20 \mathrm{~g} / 15$ plants and gibberellic acid $150 \mathrm{ppm}$ spray at $30 \mathrm{DAT}), \mathrm{A}_{2} \mathrm{G}_{1}$ (Azotobacter by soil treatment $0.40 \mathrm{~g} / \mathrm{plot}$ and gibberellic acid $100 \mathrm{ppm}$ spray at 30 DAT ), $\mathrm{A}_{2} \mathrm{G}_{2}$ (Azotobacter by soil treatment $0.40 \mathrm{~g} / \mathrm{plot}$ and gibberellic acid $150 \mathrm{ppm}$ spray at 30 DAT) and $A_{0} G_{0}$ (No Azotobacter and no gibbrellic acid) were evaluated in Randomized Block Design with three replications. The experimental finding revealed that the treatment $\mathrm{A}_{2} \mathrm{G}_{2}($ Soil treatment with Azotobacter + spray of GA @ $150 \mathrm{ppm}$ ) gave the maximum plant height, maximum number of primary branches per plant, maximum number of secondary branches per plant, maximum plant spread, minimum number of days taken for flower bud appearance, maximum number of flowers per plant, maximum flower diameter, maximum fresh weight of flowers per plant and maximum yield of flower in comparison to individual application of $\mathrm{GA}_{3}$ and Azotobacter.

KEY WORDS : Bio fertilizer, Plant growth regulator, Growth, Flowering, Yield, Marigold

HOW TO CITE THIS ARTICLE : Kumar, Naresh, Kumar, Jitendra, Singh, J.P., Kaushik, Himanshu and Singh, R.K. (2016). Effect of $\mathrm{GA}_{3}$ and Azotobacter on growth and flowering in African marigold (Tagetes erecta L.) cv. PUSA NARANGI GAINDA. Asian J. Hort., 11(2) : 382-386, DOI : 10.15740/HAS/TAJH/11.2/ 382-386. 